\title{
Strategi Mengajarkan Keterampilan Hidup Sehari-Hari Untuk Anak dan Remaja Dengan Retardasi Mental: Sebuah Review Literatur
}

\author{
Wiyanti Maratus Sholihah \\ Wiyanti.maratus.olihah-2018@psikologi.unair.ac.id \\ Magister Psikologi \\ Fakultas Psikologi \\ Universitas Airlangga
}

\begin{abstract}
Abstrak
Program pendidikan untuk siswa dengan retardasi mental menekankan pada persiapan siswa untuk hidup mandiri setelah selesai sekolah. Salah satu strategi pendidikan untuk anak dan remaja dengan retardasi mental adalah mengajarkan keterampilan hidup sehari-hari. Tujuan studi ini adalah untuk melakukan review literatur mengenai strategi mengajarkan keterampilan hidup sehari-hari untuk anak dan remaja dengan retardasi mental. Pencarian literatur dilakukan pada tujuh basis data, yaitu ERIC, SpringerLink, ScienceDirect, SAGE, JSTOR, Emerald Insight dan Google Schoolar. Kata kunci yang digunakan dalam pencarian ini adalah "teaching daily living skill" and "mental retardation"; "teaching daily living skill" and "intellectual disability". Total 5 artikel $(\mathrm{N}=614)$ akan direview dengan melalui proses skrining berdasarkan kriteria inklusif dan eklusif. Hasil menunjukkan bahwa terdapat strategi untuk mengajarkan keterampilan hidup sehari-hari pada anak dan remaja dengan retardasi mental yaitu dengan menggunakan video prompting, video modelling, constant-time delay dan most-to-least prompt procedures.
\end{abstract}

Kata kunci: keterampilan hidup sehari-hari; retardasi mental; video prompting; video modelling; constant-time delay; most-to-least prompt procedures; literature review

\section{Abstract}

Educational programs for students with mental retardation emphasize the preparation of students to live independently after finishing school. One educational strategy for children and adolescents with mental retardation is to teach daily life skills. The purpose of this study is to conduct a literature review on strategies to teach daily life skills to children and adolescents with mental retardation. Literature searches were carried out on seven databases, namely ERIC, SpringerLink, ScienceDirect, SAGE, JSTOR, Emerald Insight and Google Schoolar. The keywords used in this search are "teaching daily living skills" and "mental retardation"; "Teaching daily living skills" and "intellectual disability". A total of 5 articles $(N=$ 614) will be reviewed through a screening process based on inclusive and exclusive criteria. The results show that there are strategies to teach daily life skills to children and adolescents with mental retardation by using video prompting, video modeling, constant-time delay and most-to-least prompt.

Keyword: daily living skills; mental retardation; video prompting; video modeling; constant-time delay; most-to-least prompt procedures; literature review 
Jurnal PINUS: Jurnal Penelitian Inovasi Pembelajaran, 6 (2), 2021, Wiyanti Maratus Sholihah

\section{PENDAHULUAN}

\section{Menurut AAMR (American Association on Mental Retardation) Retardasi mental adalah keterbatasan yang signifikan dalam berfungsi baik secara intelektual yang ditentukan melalui tes intelegensi maupun perilaku yang merujuk pada kemampuan} konseptual, sosial dan praktikal. Keadaaan ini muncul sebelum usia 18 tahun (Hallahan \& Kauffman, 2011).

Retardasi mental terkait dengan keterbatasan dalam perilaku adaptif atau keterampilan hidup berikut: komunikasi, perawatan diri, kehidupan rumah, keterampilan sosial, kehidupan masyarakat, pengarahan diri sendiri, kesehatan dan keselamatan, fungsi akademik, rekreasi dan pekerjaan. Klasifikasi retardasi mental menurut APA terbagi menjadi 4 kategori yaitu: 1) Mild dengan IQ 55-70, 2) Moderate dengan IQ 40-55, 3) Severe denganIQ 25$40,4)$ Profound dengan IQ dibawah 25 (Mangunsong, 2009)

Musyrifah, Roswita \& Sumijati (2012) menyatakan bahwa pada siswa dengan retardasi mental, kemampuan berfikir yang dimilikinya berada dibawah rata-rata sehingga siswa umumnya mengalami hambatan dalam kemampuan akademiknya. Mereka memiliki keterbatasan kemampuan dalam memperoleh prestasi akademis, sehingga hal yang paling mungkin untuk dikembangkan pada siswa dengan retardasi mental sedang adalah pengembangan keterampilanketerampilan hidup dengan latihan yang rutin. Penelitian di SLB N Semarang diperoleh masih banyaknya siswa dengan retardasi mental yang bergantung pada orangdi sekitarnya dalam melakukan keterampilan hidup sehari-hari (misal: makan, memakai baju, berpergian, membuat makanan). Penelitian lain dilakukan oleh Faikoh, Alfiyanti \& Nurullita (2014) menyatakan bahwa 50\% siswa dengan retardasi mental di SLB N Semarang tidak mampu untuk melakukan toilet training.

Pendidikan untuk siswa dengan retardasi mental harusnya pendidikan yang menyediakan pengalaman yang bermakna yang akan membantu siswa untuk menyiapkan hidupnya kelak dan menerapkan pendidikan yang diperolehnya dalam kehidupan seharihari. Oleh karena itu, kurikulum untuk siswa dengan retardasi mental harus menekankan pada persiapan siswa untuk hidup setelah lulus sekolah. Kurikulum untuk siswa dengan retardasi mental kategori sedang menekankan pada keterampilan merawat diri, interaksi sosial, rekreasi, keterampilan untuk bersenang-senang dan pelatihan kerja (Hunt \& Marshall, 2005).

Konten akademik dan fungsi akademik pada siswa dengan retardasi mental fokus pada kegiatan yang menunjang kemandirian siswa, seperti fokus pada managemen diri dan kesehatan diri, menanam dan berkebun. Keterampilan akademik dasar diajarkan seperti membaca, menulis dan aritmatika. Keterampilan membaca ditampilkan pada kontek membaca menu, list filem, label pakaian, rambu-rambu lalu lintas dan arah mata angin. Keterampilan aritmatik ditampilkan pada kontek membayar 
Jurnal PINUS: Jurnal Penelitian Inovasi Pembelajaran, 6 (2), 2021, Wiyanti Maratus Sholihah

makanan di restoran, toko, dan warung, menggunakan mesin otomatis untuk membeli minuman, dan merencanakan keuangan mingguan. Fungsi akademik pada setting kelas yang terpisah lebih cenderung terikat pada tugas yang spesifik seperti kelas yang fokus pada keterampilan memasak, berbelanja dan menyiapkan makanan (Hunt \& Marshall, 2005).

Berdasarkan uraian di atas diketahui bahwa pendidikan untuk siswa dengan retardasi mental mengajarkan tentang keterampilan hidup sehari-hari. Namun masih terdapat tantangan yang dihadapi oleh guru dalam mengajarkan keterampilan hidup sehari-hari pada siswa dengan retardasi mental. Penelitian lain menemukan bahwa siswa dengan retardasi mental tidak diajarkan keterampilan hidup sehari-hari secara efektif. Studi ini juga menemukan bahwa tujuh puluh delapan persen (78\%) guru di unit untuk siswa dengan retardasi mental tidak dilatih untuk mengajar siswa tersebut. Tantangan yang dihadapi guru dalam mengajarkan keterampilan hidup sehari-hari adalah: Kurangnya bahan mengajar; kekurangan dana; sikap negatif guru terhadap siswa dengan retardasi mental; kurangnya tenaga terlatih dan kekurangan gedung sekolah sehingga siswa retardasi mental dicampur dengan siswa regular(Ruteere, Mutia, Mwoma, \& Runo, 2015).

Parmenter (1993 ) dalam (Ramdoss et al., 2012) menyebutkan bahwaketerampilan hidup sehari-hari dianggap penting untuk meningkatkan kemandirian. Terlepas dari apakah seorang individu memiliki retardasi mental ringan atau berat, perolehan keterampilan ini dapat menyebabkan peningkatan kemandirian dan diperkirakan mengurangi sikap pasif dan belajar ketidakberdayaan. Selama empat dekade terakhir, sejumlah besar perhatian telah diarahkan mengembangkan strategi pembelajaran yang efektif untuk mengajar keterampilan sehari-hari hidup untuk individu dengan retardasi mental.

Keterampilan hidup sehari-hari untuk siswa dengan retardasi mental diajarkan menggunakan berbagai teknik dan dengan menggunakan beberapa media. Salah satu pendekatan pembelajaran yang telah digunakan untuk mengajarkan keterampilan hidup seharihari adalah:1) Constant-time delaydanmost-to-least prompt proceduresefektif dalam mengajarkan keterampilan hidup sehari-hari(Ç Aykut, 2012). 2) Video modelling. Video modelling dapat digunakan untuk membantu siswa dengan retardasi mental untuk memperoleh keterampilan menyapa orang dan setelah mendapatkan keterampilan mereka terus menggunakan keterampilan dan telah menunjukkan bahwa mereka terus menggunakan dalam situasi yang berbeda dan untuk orang yang berbeda (Avcıoğlu, 2013). 3) Video prompting. Aykut dkk (2014) menjelaskan bahwa video prompting mampu meningkatkan keterampilan hidup sehari-hari. Subjek mampu menerapkan dan melakukan keterampilan ini jauh dari lingkungan pengajaran, dan mampu mempertahankan keterampilan mereka .

Tujuan penelitian ini adalah untuk melakukan review beberapa studi tentang 
Jurnal PINUS: Jurnal Penelitian Inovasi Pembelajaran, 6 (2), 2021, Wiyanti Maratus Sholihah

mengajarkan keterampilan hidup seharihari pada anak dan remaja dengan retardasi mental. Review literatur pada studi ini akan mendiskusikan khususnya pada strategi mengajarkan keterampilan hidup sehari-hari pada anak dan remaja dengan retardasi mental.

\section{METODE}

Penelitian ini merupakan review literatur. Review literatur adalah survei artikel ilmiah, buku dan sumber lain yang relevan dengan suatu hal tertentu, masalah, bidang penelitian, atau teori, dan dengan demikian, memberikan deskripsi, ringkasan, dan evaluasi kritis terhadap penelitian yang ada (Ramdhani, Ramdhani \& Amin, 2014).

Guritno, dkk.

mengemukakan bahwa review literatur diperlukan untuk 1) Berbagi informasi kepada pembaca tentang hasil penelitian sebelumnya. 2) Menghubungkan suatu penelitian menjadi lebih luas dan berkelanjutan. 3) Kerangka kerja untuk menunjukkan atau meyakinkan pentingnya penelitian dan membandingkan hasil penelitian.

Ramdhani, Ramdhani \& Amin, (2014) menjelaskan Langkah-langkah melakukan review literatur. 1) memilih topik yang akan direview. 2) Mencari dan memilih artikel yang sesuai. 3) Menganalisis dan mensintesis literatur. 4) Penulisan review. 5) Kesimpulan.

Review literatur dilakukan dengan melakukan pencarian literatur online dilakukan melalui 7 database, yaitu ERIC dengan alamat URL ERIC.edu.gov; Springer Link dengan alamat URL link.springer.com;
ScienceDirect dengan alamat URL sciencedirect.com; SAGE JOURNALS dengan alamat URL journals.sagepub.com; JSTOR dengan alamat URL jstor.org; Emerald Insightdengan alamat URL emeraldinsight.com dan Google Schoolar dengan alamat URL scholar.google.co.id. Pencarian dilakukan selama satu minggu dari 05-12 Agustus 2019 dengan rentang publikasi terbatas pada 10 tahun terakhir (2009-2019). Kata kunci yang digunakan dalam pencarian literature adalah "teaching daily living skill" and "mental retardation"; "teaching daily living skill"and "intellectual disability".

Terdapat serangkaian kriteria inklusi dan eksklusi untuk pencarian literature ini. Kriteria inklusi yaitu; Memeriksa teaching daily living skill pada anak dan remaja dengan retardasi mental. Sementara itu kriteria eksklusi terdiri dari: 1) Jurnal menggunakan bahasa inggris; 2) Teks lengkap dapat diunduh; 3) Partisipan atau subjek adalah anak dan remaja dengan retardasi mental. Pencarian awal ditemukan literatur sebanyak 614 artikel, setelah dilakukan proses seleksi berdasarkankriteria inklusi dan eksklusi diperoleh 5 artikel. Proses seleksi dilakukan dengan mengidentikasi: Penulis, konten, tahun publikasi, tujuan penelitian, ukuran sampel, metode penelitian dan instrument pengumpulan data yang digunakan dan hasil penelitian. Hasilnya 5 artikel ditinjau secara sistematis.

\section{HASIL}

Studi yang sudah diseleksi, dirangkum berdasarkan pada jenis 
Jurnal PINUS: Jurnal Penelitian Inovasi Pembelajaran, 6 (2), 2021, Wiyanti Maratus Sholihah

penelitian, jumlah sampel dan temuan hidup sehari-hari pada anak dan remaja mengenai strategi mengajar keterampilan dengan retardasi mental.

Tabel 1. Rangkuman artikel temuan

\begin{tabular}{|c|c|c|c|}
\hline $\begin{array}{l}\text { Penulis } \\
\text { (Tahun) }\end{array}$ & Subjek & Metode Penelitian & Temuan \\
\hline Aykut (2012) & $\begin{array}{l}\text { Subjek adalah } 4 \\
\text { siswa sekolah } \\
\text { dasar }\end{array}$ & $\begin{array}{l}\text { Desain single } \\
\text { subjek ekperimen. } \\
\text { Setting penelitian } \\
\text { di dapur sekolahan } \\
\text { untuk } \\
\text { memasak. } \\
\text { Memasak sup } \\
\text { instan } \\
\text { keterampilan } \\
\text { menjahit adalah } \\
\text { dependent variable } \\
\text { dan Constant-Time } \\
\text { Delay dan Most-to- } \\
\text { least Prompt } \\
\text { Procedures } \\
\text { merupakan } \\
\text { variable } \\
\text { independen }\end{array}$ & $\begin{array}{l}\text { Hasilnya menunjukkan } \\
\text { bahwa,most-to-least prompt } \\
\text { procedures lebih efisien } \\
\text { daripada prosedur constant- } \\
\text { time delay dalam hal total } \\
\text { waktu pelatihan, jumlah } \\
\text { percobaan dan kesalahan } \\
\text { pelatihan. Kedua strategi } \\
\text { ditemukan memiliki } \\
\text { efektivitas yang sama dalam } \\
\text { pemeliharaan dan } \\
\text { generalisasi } \\
\text { keterampilan hidup sehari- } \\
\text { hari. }\end{array}$ \\
\hline $\begin{array}{l}\text { Avcioğlu } \\
(2013)\end{array}$ & $\begin{array}{lr}3 & \text { siswa } \\
\text { perempuan dan2 } \\
\text { laki-laki } \\
\text { sekolah di } \\
\text { yang mengalami } \\
\text { retardasi mental } \\
\text { yang berusia } 11 \\
\text { tahun ran } \\
\text { berada di } & \text { kelas } \\
5 . & \end{array}$ & $\begin{array}{l}\text { Eksperimen desain } \\
\text { single subjek }\end{array}$ & $\begin{array}{lr}\text { Temuan } & \text { penelitian } \\
\text { menunjukkan } & \text { bahwa } \\
\text { dengan menggunakan video } \\
\text { modeling dalam mengajar } \\
\text { siswa dengan retardasi } \\
\text { mental membantu mereka } \\
\text { untuk memperoleh } \\
\text { keterampilan menyapa } \\
\text { orang dan setelah } \\
\text { mendapatkan keterampilan } \\
\text { mereka terus menggunakan } \\
\text { keterampilan dan telah } \\
\text { menunjukkan } \\
\text { mereka terus menggunakan } \\
\text { dalam situasi yang berbeda }\end{array}$ \\
\hline
\end{tabular}


Jurnal PINUS: Jurnal Penelitian Inovasi Pembelajaran, 6 (2), 2021, Wiyanti Maratus Sholihah

\begin{tabular}{|c|c|c|c|}
\hline & & & $\begin{array}{l}\text { dan untuk orang yang } \\
\text { berbeda }\end{array}$ \\
\hline $\begin{array}{l}\text { Aykut dkk } \\
(2014)\end{array}$ & $\begin{array}{lr}3 \text { Siswa } & \text { dengan } \\
\text { retardasi } & \text { mental } \\
\text { kategori } & \text { sedang } \\
\text { disebuah } & \\
\text { sekolah } & \text { di } \\
\text { Ankara } & \text { Turki. } \\
\text { Usia } & 11-13 \\
\text { tahun. } & \end{array}$ & $\begin{array}{l}\text { Desain eksperimen } \\
\text { multi-probe dari } \\
\text { metode desain } \\
\text { subjek tunggal } \\
\text { telah diterapkan } \\
\text { pada penelitian ini }\end{array}$ & $\begin{array}{l}\text { Temuan ini memberikan } \\
\text { bukti untuk efektivitas video } \\
\text { prompting dalam } \\
\text { meningkatkan keterampilan } \\
\text { hidup sehari-hari. Subjek } \\
\text { mampu menerapkan dan } \\
\text { melakukan keterampilan ini } \\
\text { jauh dari lingkungan } \\
\text { pengajaran, dan mampu } \\
\text { mempertahankan } \\
\text { keterampilan mereka yang } \\
\text { meningkat selama } 6 \text { bulan } \\
\text { berikutnya. }\end{array}$ \\
\hline $\begin{array}{l}\text { Canella dkk } \\
(2011)\end{array}$ & $\begin{array}{l}\text { Subyek adalah } 7 \\
\text { siswa dengan } \\
\text { retardasi mental } \\
\text { kategori berat }\end{array}$ & Ekperimen & $\begin{array}{l}\text { Video prompting lebih } \\
\text { efektif daripada video } \\
\text { modeling, yang umumnya } \\
\text { tidak efektif. Untuk satu } \\
\text { peserta, baik video } \\
\text { modeling atau video } \\
\text { prompt tidak efektif, tetapi } \\
\text { instruksi in vivo mengarah } \\
\text { pada perolehan } \\
\text { keterampilan. Salah satu } \\
\text { peserta yang tuli juga } \\
\text { dapatmempelajari kedua } \\
\text { keterampilan menggunakan } \\
\text { bisikan video, meskipun dia } \\
\text { tidak bisa mendengar } \\
\text { instruksi pengisi suara. Data } \\
\text { ini menunjukkan bahwa } \\
\text { durasi video dapat } \\
\text { mempengaruhi } \\
\text { efektivitasnya sebagai alat } \\
\text { pengajaran }\end{array}$ \\
\hline $\begin{array}{l}\text { Payne dkk } \\
(2012)\end{array}$ & $\begin{array}{l}\text { Subjek adalah } 2 \\
\text { siswa dengan } \\
\text { retardasi mental }\end{array}$ & $\begin{array}{l}\text { Desain eksperimen } \\
\text { Probe ganda di } \\
\text { seluruh peserta }\end{array}$ & $\begin{array}{l}\text { Kedua siswa belajar } \\
\text { membuat popcorn dengan } \\
\text { menggunakan microwave. }\end{array}$ \\
\hline
\end{tabular}


Jurnal PINUS: Jurnal Penelitian Inovasi Pembelajaran, 6 (2), 2021, Wiyanti Maratus Sholihah

\begin{tabular}{llll}
\hline kategori sedang & desain digunakan & Seorang siswa belajar untuk \\
dan berat & untuk & mengoperasikan sendiri \\
& mengevaluasi efek & iPod Touch dan memenuhi \\
& dari & video & kriteria untuk memulai fase \\
& prompting dan & 3 (membuat sup mie) \\
& akuisisi r dari & \\
& dorongan video \\
& yang diarahkan \\
& sendiri \\
\hline
\end{tabular}

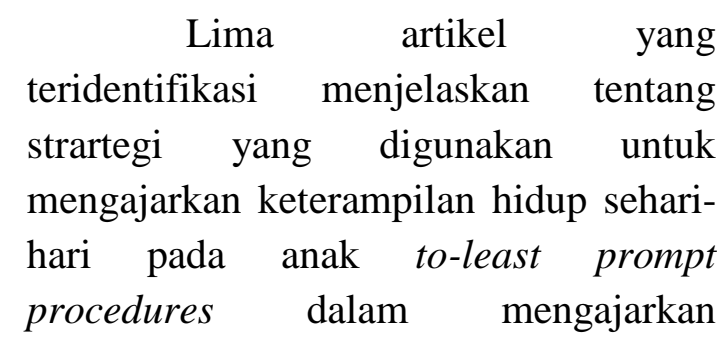
keterampilan hidup sehari-hari pada anak retardasi mental. Dua subjek, pada akhir instruksi untuk setiapprosedur, berhasil mencapai kedua keterampilan hidup sehari-hari pada level $100 \%$. Instruksi oleh kedua prosedur cukup efisien untuk subjek pertama untuk mendapatkan keterampilan hidup sehari-hari. Terlihat bahwa subjek mempertahankan keterampilan hidup sehari-hari yang diperoleh dengan penundaan waktu terusmenerus dan dorongan yang paling rendah (menjahit,memanaskan sup siap pakai) pada tingkat $100 \%$ selama 1,2 , dan 4 minggu dan menggeneralisasi harian keterampilan hidup dan remaja dengan retardasi mental. Penelitian Aykut (2012) bertujuan untuk mengetahui efektifitas constant-time delaydanmost.

Avcioğlu (2013) melakukan penelitian mengenai efek video modelling untuk siswa dengan retardasi mental ketika bertemu dengan orang lain. Variabel independen adalah siswa mempunyai keterampilan untuk menyapa orang lain berdasarkan implementasi video modelling. Variabel dependent adalah level belajar dari target siswa untuk menyapa orang lain yang mereka kenali. Target kemampuan meliputi :

1. Menyadari orang yang mereka kenal ketika mereka saling bertemu

2. Untuk mendekati orang yang mereka kenal ketika saling bertemu

3. Melihat wajah orang yang mereka kenali

4. Menyapa dengan menggunakan katakata selaamat pagi, halo, hi.

5. Menunggu jawaban orang tersebut

$$
\text { (Çiğil Aykut, Dağseven }
$$

Emecen, Dayi, \& Karasu, 2014) melakukan penelitian tentang mengajarkan keterampilan hidup seharihari kepada siswa dengan retardasi mental dengan menggunakan video prompt. Dalam penelitian ini subjek mampu mempelajari keterampilan hidup sehari-hari dan menerapkan keterampilan yang diperoleh dalam kehidupan seharihari.

$$
\text { (Cannella-Malone et al., }
$$
2011)membandingkan efek darivideo prompting dan video modelling untuk mengajar tujuh siswa penyandang 
Jurnal PINUS: Jurnal Penelitian Inovasi Pembelajaran, 6 (2), 2021, Wiyanti Maratus Sholihah

retardasi mental untuk mencuci dan mencuci piring. Hasilnya Video prompting lebih efektif daripada video modelling.

(Payne, Cannella-Malone, Tullis, \& Sabielny, 2012) mengevaluasi efektivitas video prompt disajikan pada iPod Touch pada dua keterampilan hidup sehari-hari, serta sistem most-to-least prompts untuk mengajar dua siswa retardasi mental sedang dan berat untuk menggunakan iPod Touch. Hasilnya kedua siswa mampu melakukan dua keterampilan hidup sehari-hari yaitu membuat popcorn dengan menggunakan

microwave dan mampu membuat sup mie.

\section{PEMBAHASAN}

Berdasarkan temuan pada artikel yang telah direview diketahui bahwa strategi untuk mengajarkan keterampilan hidup sehari-hari pada anak dan remaja dengan retardasi mental adalah video prompting, video meodeling, dan constant-time delay (CTD dan most-to-least prompt.

Tabel 2. Strategi Mengajarkan Keterampilan Hidup Untuk Anak dan Remaja dengan Retardasi Mental

\begin{tabular}{lll}
\hline No & Artikel & Strategi \\
\hline 1 & Aykut (2012) & Constant-time delay (CTD). Pada CTD, setelah memberikan \\
& arahan terhadap keterampilan yang diajarkan, penundaan \\
& waktu yang konstan diberikan sebelum prompt diberikan \\
& dengan tujuan siswa berhasil mencapai keterampilan secara \\
& mandiri. Prosedur CTD terdiri dari dua tahap: (1) prosedur \\
& pengajaran penundaan nol detik dan (2) prosedur pengajaran \\
& penundaan 4-5 detik. Ketika instruksi yang diberikan kepada \\
& siswa untuk mencapai tahap keterampilan dihapus dari segi \\
& waktu, dan tidak ada perubahan dalam bentuk atau jumlahnya \\
& dari prompt maka prompt akan dihapus.
\end{tabular}

Most-To-Least Prompt. Didesain sebagai pengurangan promt sampai dihapusnya promt terakhir setelah pengajaran dimulai dengan menawarkan promt yang membuat siswa membuat reaksi yang tepat. Pengurangan promt dapat dilakukan dengan 3 cara (1) perlahan menukar jenis promt. (2) perlahan menukar jumlah promt. (3) menukar masing-masing dua promt yang akan membuat siswa bereaksi dengan benar. Dengan mengembalikan prompt dalam bentuk jenis, jumlahnya atau keduanya, tujuannya adalah memungkinkan siswa untuk melakukannya tugas secara mandiri. 
Jurnal PINUS: Jurnal Penelitian Inovasi Pembelajaran, 6 (2), 2021, Wiyanti Maratus Sholihah

\begin{tabular}{lll}
\hline 2 & $\begin{array}{l}\text { Avcioğlu } \\
(2013)\end{array}$ & $\begin{array}{l}\text { Video modelling. Terdiri dari video tunggal yang menyajikan } \\
\text { model yang melakukan tugas dari awal hingga akhir perilaku } \\
\text { target atau menyelesaikan tugas yang dirancang. }\end{array}$ \\
\hline 3 & $\begin{array}{l}\text { Aykut et all., } \\
\text { (2014); }\end{array}$ & $\begin{array}{l}\text { Video prompting.menggabungkan petunjuk visual dan } \\
\text { pendengaran yang membutuhkan siswa untuk melihat satu } \\
\text { Cannella- }\end{array}$ \\
$\begin{array}{l}\text { Malone et al., } \\
\text { (2011); Payne }\end{array}$ & tersebut sebelum menonton klip video berikutnya dan \\
et all., (2012) &
\end{tabular}

Penggunaan teknologi untuk dijadikan media pembelajaran untuk siswa dengan retardasi mental mengakibatkan peningkatan keterampilan akuisisi, pemeliharaan dangeneralisasi dengan demikian, menunjukkan potensi penggunaan teknologi berkelanjutan dalam instruksi untuk siswa dengan retardasi mental. Dua strategidigunakan untuk keterampilan mengajar kepada siswa dengan retardasi mental. menggabungkan teknologi video untuk instruksi dalam bentuk video prompting dan video modeling (Taberdoughty et al., 2015)

Siswa berhasil melakukan tugas mandiri dengan menggunakan video prompting dan video modeling. Peningkatan kemandirian terlihat jelas untuk setiap siswa berkisar dari $42.8 \%$ sampai 58.5\% sebelum intervensi, setelah menggunakan video prompting, kemandirian meningkat menjadi $65.3 \%$ menjadi $78.5 \%$ sedangkan setelah menggunakan video modeling, kemandirian siswa meningkat menjadi 87\% (Taber-doughty et al., 2015)

Video prompting merupakan pengajaran instruksional menggunakan teknologi video yang berbeda dibandingkan denganvideo modeling dalam dua cara yang berbeda. Video prompting terdiri dari memperlihatkan setiap langkah dari tugas dan memberikan kesempatan kepada peserta untuk melakukan langkah itu sebelum melanjutkan untuk melihat langkah selanjutnya dalam analisis tugas yang direkam(Koutromanos, 2017)

Video prompting telah berhasil mengajarkan kemandirian pada siswa dengan retardasi mental seperti pengaturan kerja, menggunakan ATM dan mesin debit, untuk keterampilan hidup sehari-hari, untuk berbelanja bahan makanan, dan keterampilan memasak (Taber-doughty et al., 2015).

Keberhasilan serupa juga ditemukan dengan video modeling di mana siswa melakukan tugas dalam pengaturan yang sama atau alternatif tanpa tambahan disuruh hanya setelah melihat seluruh urutan tugas. Hal yang berbeda dalam video modeling, selain tugas, adalah delay antara melihat video dan kinerja aktual dari tugas. penundaan dilaporkan antara melihat video dan melakukan tugas segera setelah melihat video (Taber-doughty et al., 2015). Individu harus menonton video dengan waktu yang relatif singkat dibandingkan dengandurasi video yang lebih lama 
Jurnal PINUS: Jurnal Penelitian Inovasi Pembelajaran, 6 (2), 2021, Wiyanti Maratus Sholihah

digunakan dalam kasus terakhir(Koutromanos, 2017)

Strategi lain untuk mengajarkan keterampilan hidup sehari-hari yaitu constant-time delay (CTD). Prosedur CTD dapat dipandang sebagai prosedur pembelajaran yang hampir tanpa kesalahan yang secara sistematis memudarkan dorongan awal atau kontrol terhadap stimulus diskriminatif alami. Penggunaan video prompting dibarengi dengan CTD dan prosedur error correction efektif digunakan untuk mengajarkan keterampilan menggunakan internet (Koutromanos, 2017)

Penelitian yang dilakukan oleh Aykut (2012) menjelaskan bahwa prosedur constant-time delay (CTD) danmost-to-least prompt efektif digunakan untuk mengajarkan keterampilan hidup sehari-hari pada siswa retardasi mental. Dua subjek, pada akhir instruksi untuk setiap prosedur, berhasil mencapai kedua keterampilan hidup sehari-hari pada level 100\%. Sebagai hasilnya, instruksi oleh kedua prosedur cukup efisien untuk subjek pertama untuk mendapatkan keterampilan hidup sehari-hari. Terlihat bahwa subjek mempertahankan keterampilan hidup sehari-hari yang diperoleh dengan penundaan waktu terusmenerus dan dorongan yang paling rendah (menjahit, memanaskan sup siap pakai) pada tingkat $100 \%$ selama 1,2 , dan 4 minggu dan menggeneralisasi harian keterampilan hidup(Ç Aykut, 2012)

Terdapat beberapa keterbatasan dalam review ini. Pertama pada strategi pencarian artikel tidak mencantumkan kata kunci setting penelitian, jadi artikel yang didapat masih dalam setting yang luas. Kedua adalah review dilakukan oleh satu orang, sehingga memungkinkan untuk terjadi bias.

\section{KESIMPULAN}

$\begin{array}{clr}\text { Retardasi } & \text { mental } & \text { adalah } \\ \text { keterbatasan yang } & \text { signifikan } & \text { dalam }\end{array}$ berfungsi baik secara intelektual yang ditentukan melalui tes intelegensi dan perilaku adaptif yang merujuk pada kemampuan konseptual, sosial dan praktikal. Keadaaan ini muncul sebelum usia 18 tahun. Program pendidikan untuk siswa dengan retardasi mental menekankan pada persiapan siswa untuk hidup mandiri keterampilan hidup seharihari pada anak dan remaja dengan retardasi mental, yaitu dengan menggunakan video prompting, video modelling, constant-time delay dan mostto-least prompt procedures. Implikasi dari tinjauan ini adalah menyediakan beberapa metode atau strategi bagi guru maupun masyarakat untuk mengajar siswa dengan retardasi mental.

\section{DAFTAR RUJUKAN}

Avcioğlu, H. (2013). Effectiveness of Video Modelling in Training Students with Intellectual Disabilities to Greet People When They. Educational Sciences: Theory \& Practice, 13(1), 466-478.

Aykut, Ç. (2012). Effectiveness and Efficiency of Constant-Time Delay and Most-to-least Prompt Procedures in Teaching Daily Living Skills to Children with Intellectual Disabilities. Educational Sciences: Theory \& Practice, 12(1), 366-373. 
Jurnal PINUS: Jurnal Penelitian Inovasi Pembelajaran, 6 (2), 2021, Wiyanti Maratus Sholihah

Aykut, Çiğil, Dağseven Emecen, D., Dayi, E., \& Karasu, N. (2014). Zihin engelli öğrencilere küçük grup öğretimi sirasinda video ipucu kullanilarak zincirleme becerilerin kazandirilmasi. Kuram ve Uygulamada Egitim Bilimleri, 14(3), 1075-1087. https://doi.org/10.12738/estp.2014. 3.1984

Cannella-Malone, H. I., Fleming, C., Chung, Y. C., Wheeler, G. M., Basbagill, A. R., \& Singh, A. H. (2011). Teaching daily living skills to seven individuals with severe intellectual disabilities: A comparison of video prompting to video modeling. Journal of Positive Behavior Interventions, 13(3), 144153.

https://doi.org/10.1177/1098300710 366593

Faikoh, N. Alfiyanti, D. Nurullita, U. (2014). Pengaruh Modelling Media Video Terhadap Peningkatan Kemampuan Toilet Training Pada Anak Retardasi Mental Usia 5-7 Tahun Di Slb N Semarang. karya Ilmiah Stikes Telogorejo. 3 (1)

Guritno, S., Sudaryono, \& Rahardja, U. (2011). Theory and Application of IT Research: Metodologi Penelitian Teknologi Informasi. Yogyakarta: Andi.

Hallahan, D.P. \& Kauffman, J.M. (2011). Exceptional Children. New Jersey: Prentice Hall,Inc.

Hunt, N. \& Marshall, K. 2005. Exceptional Children and Youth. Boston: Houghton Mifflin Company.

Koutromanos, G. (2017). Division on Autism and Developmental Disabilities Using Video Prompting and Constant Time Delay to Teach an Internet Search Basic Skill to Students with Intellectual
Disabilities Author ( $s$ ): Dimitrios Zisimopoulos , Jeff Sigafoos and George Koutromanos . 46(2).

Mangunsong, F. 2009. Psikologi dan Pendidikan Anak Berkebutuhan Khusus Jilid I. Jakarta: Lembaga Pengembangan Sarana Pengukuran dan Pendidikan Psikologi (LPSP3) Kampus Baru UI, Depok.

Musyrifah, Roswita \& Sumijati (2012). Efek Video Modeling Untuk Mengajarkan Keterampilan Mencuci Baju Pada Individu Retardasi Mental Sedang. Prediksi, Kajian Ilmiah Psikologi. 1 (2).

Payne, D., Cannella-Malone, H. I., Tullis, C. A., \& Sabielny, L. M. (2012). The Effects of Self-Directed Video Prompting With Two Students With Intellectual and Developmental Disabilities. Journal of Developmental and Physical Disabilities, 24(6), 617-634. https://doi.org/10.1007/s10882-0129293-1

Ramdhani, A., Ramdhani, M. A., \& Amin, S.A. (2014). Writing a Literature Review Research Paper: A step-by-step approach. International Journal of Basic and Applied Science, 1(3): 47-56.

Ramdoss, S., Lang, R., Fragale, C., Britt, C., O'Reilly, M., Sigafoos, J., ... Lancioni, G. E. (2012). Use of computer-based interventions to promote daily living skills in individuals with intellectual disabilities: A systematic review. Journal of Developmental and Physical Disabilities, 24(2), 197215.

https://doi.org/10.1007/s10882-0119259-8

Ruteere, R. K., Mutia, J. M., Mwoma, T., \& Runo, M. (2015). Challenges Experienced in Teaching Daily Living Skills to Learners with 
Jurnal PINUS: Jurnal Penelitian Inovasi Pembelajaran, 6 (2), 2021, Wiyanti Maratus Sholihah

Mental Retardation. Journal of Education and Practice, 6(18), 159163. Retrieved from http://search.ebscohost.com/login.as $\mathrm{px}$ ?direct $=$ true $\& \mathrm{db}=$ eric $\& \mathrm{AN}=\mathrm{EJ} 10$ $79775 \&$ site $=$ ehost-live

Taber-doughty, A. T., Bouck, E. C., Tom, K., Jasper, A. D., Sara, M., Education, S., ... Jasper, D. (2015). Video Modeling and Prompting : A Comparison of Two Strategies for Teaching Cooking Skills to Students with Mild Intellectual Disabilities Published by: Division on Autism and Developmental Disabilities Video Modeling and Prompting : A Comparison of Two S. 46(4).

Akselerasi Dan Siswa Kelas Reguler Di SMAN RSBI Se-Kota Malang. Nusantara of Research: Jurnal Hasil-Hasil Penelitian Universitas Nusantara PGRI Kediri, 3(1).

Nawantara, R. D. (2017). Interpersonal Conflict Resolution Skill (Solusi Konstrukstif Bagi Konflik Interpersonal Siswa). Seminar Nasional Bimbingan Konseling Universitas Ahmad Dahlan.

Porter, L. (2005). Gifted Young Children: Meeting Their Needs. Early Childhood Australia Inc.

Sugiarti, Rini., Suhariadi, Fendi. (2015). Gambaran Kompetensi Sosial Siswa Cerdas Istimewa. Seminar Psikologi \& Kemanusiaan. 